\title{
Use of fluorescence ratio imaging for intracellular pH determination of individual bacterial cells in mixed cultures
}

\author{
Henrik Siegumfeldt, K. Björn Rechinger and Mogens Jakobsen
}

Author for correspondence: Henrik Siegumfeldt. Tel: +453528 3286. Fax: +4535283214. e-mail : hsi@kvl.dk

Department of Dairy and Food Science, Royal Veterinary and Agricultural University, Rolighedsvej 30, 1958 Frederiksberg C, Denmark
The development of a rapid method for measuring intracellular $\mathbf{p H}\left(\mathrm{pH}_{\mathrm{i}}\right)$ in single bacterial cells is described. Lactobacillus delbrueckii subsp. bulgaricus and Listeria innocua were used as test organisms. The method is based upon fluorescence microscopy and ratio imaging of cells stained with carboxyfluorescein succinimidyl ester. After staining, the bacteria were immobilized on a membrane filter and transferred to a closed perfusion chamber, allowing control of the cell environment during analysis. The set-up was optimized with regard to the use of neutral-density filters and background subtraction, for determining the excitation ratio $490 \mathrm{~nm} / 435 \mathrm{~nm}$ $\left(R_{490 / 435}\right)$ independent of the excitation light intensity, and to reduce photobleaching. This allowed for time-lapse studies with multiple exposures. To study the $\mathrm{pH}_{\mathrm{i}}$ of $\mathbf{L b}$. delbrueckii subsp. bulgaricus and $L$. innocua in response to different extracellular $\mathrm{pH}\left(\mathrm{pH}_{\mathrm{ex}}\right)$ values, an in vivo calibration curve was constructed in the $\mathrm{pH}_{\mathrm{i}}$ range $5 \cdot 0-8 \cdot 5$. Distinct differences between the two cultures were observed. $L$. innocua maintained a near-neutral $\mathrm{pH}_{\mathrm{i}}$ almost independently of $\mathrm{pH}_{\mathrm{ex}}\left(\mathbf{5 \cdot 0 - 8 \cdot 0 )}\right.$, whereas the $\mathrm{pH}_{\mathrm{i}}$ of $\mathbf{L b}$. delbrueckii subsp. bu/garicus decreased with decreasing $\mathrm{pH}_{\mathrm{ex}}$. In pure and mixed cultures at $\mathbf{p H}_{\mathrm{ex}}$ 5.0, the $\mathrm{pH}_{\mathrm{i}}$ values of $L b$. delbrueckii subsp. bulgaricus and $L$. innocua were $6.1 \pm 0.2$ and $7.5 \pm 0.2$, respectively. This difference in $\mathrm{pH}_{\mathrm{i}}$ may explain how $L b$. delbrueckii subsp. bulgaricus obtains a competitive advantage over $L$. innocua at low $\mathrm{pH}_{\mathrm{ex}}$.

Keywords: intracellular $\mathrm{pH}$, ratio imaging, single cells, Lactobacillus delbrueckii subsp. bulgaricus, Listeria innocua

\section{INTRODUCTION}

Most bacteria maintain an intracellular $\mathrm{pH}\left(\mathrm{pH}_{\mathrm{i}}\right)$ close to neutral within fairly narrow limits (Padan et al., 1981), because this enables metabolic reactions to occur even under unfavourable extracellular $\mathrm{pH}\left(\mathrm{pH}_{\mathrm{ex}}\right)$ conditions. Bacteria can be divided into three groups with regard to $\mathrm{pH}$ homeostasis: neutrophiles, acidophiles and alkalophiles. These groups differ in requirement for $\mathrm{pH}_{\text {ex }}$, but all groups maintain a $\mathrm{pH}_{\mathrm{i}}$ between 6.5 and 9.5 (White, 1995). Acidophiles maintain a large gradient between $\mathrm{pH}_{\mathrm{i}}$ and $\mathrm{pH}_{\mathrm{ex}}(\Delta \mathrm{pH})$, but are restricted to growth in very acidic environments due to an inverted membrane potential (White, 1995). In contrast, a large

Abbreviations: $\mathrm{CCD}$, charge-coupled device; $\mathrm{pH}_{\mathrm{i}}$ intracellular $\mathrm{pH} ; \mathrm{pH}_{\mathrm{ex}}$ extracellular $\mathrm{pH} ; \Delta \mathrm{pH}, \mathrm{pH}_{1}-\mathrm{pH}_{\mathrm{ex}} ; \mathrm{R}_{490 / 435}$, excitation ratio $490 \mathrm{~nm} / 435 \mathrm{~nm}$. group of acid-tolerant fermentative bacteria grows at $\mathrm{pH}$ values ranging from neutral to $\mathrm{pH} 3.5$ (Kashket, 1987; McDonald et al., 1990; Russell, 1991a). This group consists of certain ruminal bacteria (Russell, 1991b) and various species of lactic acid bacteria (Kashket, 1987). A common feature is the ability to decrease their $\mathrm{pH}_{\mathrm{i}}$ with $\mathrm{pH}_{\mathrm{ex}}$ during growth (Russell \& Hino, 1985; Nannen \& Hutkins, 1991a; Cook \& Russell, 1994), and therefore this group of bacteria does not comply with the conventional classification of $\mathrm{pH}$ homeostasis. The pronounced organic acid production of these bacteria creates an environment unfavourable for most other organisms (Russell, 1992), which is the basis of many methods of food preservation by fermentation.

Food fermentations are often carried out by a concerted or sequential microbiota as the substrate changes. This 
is the case in a two-culture system like yoghurt (Auclair \& Accolas, 1983) or more complex systems like cheese, where several micro-organisms interact (Hansen \& Jakobsen, 1997). In fermented vegetables, growth of Lactobacillus plantarum follows growth of Leuconostoc mesenteroides. The microbial succession can be explained by differing levels of acid tolerance and regulation of $\mathrm{pH}_{\mathrm{i}}$ for the two organisms (McDonald et al., 1990).

Similar differences could be important for microbial interactions between lactic acid bacteria and food-borne pathogens such as Listeria monocytogenes, a Grampositive organism physiologically and phylogenetically related to lactic acid bacteria (Holzapfel \& Wood, 1995). The pathogenic Escherichia coli $\mathrm{O} 157: \mathrm{H} 7$ has been shown to decrease its $\mathrm{pH}_{\mathrm{i}}$ and thereby resist high levels of acetic acid (Diez-Gonzales \& Russell, 1997), offering an explanation of the high acid tolerance of this serotype compared to laboratory strains like E. coli K12.

In the present work we used fluorescence microscopy and ratio imaging to measure the $\mathrm{pH}_{1}$ of Lactobacillus delbrueckii subsp. bulgaricus and Listeria innocua. Lb. delbrueckii subsp. bulgaricus is known to decrease $\mathrm{pH}_{\mathbf{i}}$ in response to $\mathrm{pH}_{\mathrm{ex}}$ (Kashket, 1987), while L. innocua maintains a near-neutral $\mathrm{pH}_{\mathrm{i}}$ at acidic $\mathrm{pH}_{\mathrm{ex}}$ (Breeuwer et al., 1996). For the first time we report a rapid method for time-lapse studies of $\mathrm{pH}_{\mathrm{i}}$ in immobilized single cells of pure and mixed cultures of bacteria.

\section{METHODS}

Chemicals. All chemicals were analytical grade from Merck, unless otherwise stated.

Bacterial strains and growth conditions. Lactobacillus delbrueckii subsp. bulgaricus (NCFB 2772, kindly provided by Dr Gert Grobben, Groningen University, The Netherlands) was grown overnight at $42{ }^{\circ} \mathrm{C}$ in MRS broth (Difco). Listeria innocua (AJL 1-3, provided by the Alfred Jørgensen Laboratory, Copenhagen, Denmark) was grown overnight at $30^{\circ} \mathrm{C}$ in $\mathrm{BHI}$ broth (Difco).

Buffers and staining solutions. Potassium phosphate buffers, adjusted to a given $\mathrm{pH}$ by mixing $50 \mathrm{mM}$ solutions of $\mathrm{KH}_{2} \mathrm{PO}_{4}$ or $\mathrm{K}_{2} \mathrm{HPO}_{4}$, were used in the $\mathrm{pH}$ range $6 \cdot 0-8 \cdot 5$. Below $\mathrm{pH} 6 \cdot 0$, buffers consisting of a mixture of citric acid $(25 \mathrm{mM})$ and $\mathrm{K}_{2} \mathrm{HPO}_{4}(50 \mathrm{mM})$ were used. When cells were energized, a $1 \mathrm{M}$ glucose stock solution was added to the respective buffer to a final concentration of $10 \mathrm{mM}$. A $5 \mu \mathrm{M}$ solution of $5(6)$ carboxyfluorescein (Sigma) was prepared from a concentrated stock solution (10 $\mathrm{mM}$ in DMSO) by dilution in potassium phosphate buffer $\mathrm{pH} 8.0$.

Fluorescent staining of cells. The following method was modified from Breeuwer et al. (1996). Cells were harvested by centrifugation $(10000 \mathrm{~g}, 2 \mathrm{~min})$ and resuspended in $50 \mathrm{mM}$ potassium phosphate buffer, $\mathrm{pH} 7 \cdot 0$, to an $\mathrm{OD}_{600}$ of $0 \cdot 6$. They were then incubated in the presence of $10 \mu \mathrm{M} 5(6)$-carboxyfluorescein diacetate succinimidyl ester (Molecular Probes) at $37^{\circ} \mathrm{C}$ for $15 \mathrm{~min}$ ( $\mathrm{Lb}$. delbrueckii subsp. bulgaricus) or $30 \mathrm{~min}$ (L. innocua and mixed-culture experiments). Afterwards, cells were washed by centrifugation $(10000 \mathrm{~g}, 2 \mathrm{~min})$ and resuspended in equivalent volumes of the buffer indicated in each experiment. Cells not analysed immediately were stored on ice in the dark for a maximum of $1 \mathrm{~h}$.

Equilibration of $\mathrm{pH}_{\mathrm{i}}$. Calibration points for $L b$. delbrueckii subsp. bulgaricus and L. innocua were determined in buffers ranging from $\mathrm{pH} 5.0$ to 8.5 . After staining and resuspension of the cultures, the $\mathrm{pH}_{\mathrm{i}}$ and $\mathrm{pH}_{\mathrm{ex}}$ were equilibrated by addition of valinomycin (Sigma) and nigericin (Molecular Probes) to a final concentration of $1 \mu \mathrm{M}$ each, followed by a $10 \mathrm{~min}$ incubation at $37^{\circ} \mathrm{C}$.

Immobilization of cells for microscopical analysis. Stained cells were diluted 100 -fold in the appropriate buffer, and $200 \mu \mathrm{l}$ aliquots were drawn through a $45 \mu \mathrm{m}$ membrane filter (Schleicher \& Schuell, ME 25/31). The portion of the membrane containing cells was excised (diameter $0.6 \mathrm{~cm}$ ) and mounted in a perfusion chamber system with a nominal volume of $250 \mu \mathrm{l}$, previously described by Guldfeldt \& Arneborg (1998). After addition of $250 \mu \mathrm{l}$ of the appropriate buffer, a small piece of large-pored foam rubber $(\sim$ $0.5 \times 0.5 \times 0.5 \mathrm{~cm}$ ) was inserted between the pressure cap and the backside of the filter to prevent movement of the membrane filter inside the chamber.

Fluorescence microscopy. The set-up was the same as described by Guldfeldt \& Arneborg (1998), and consisted of a monochromator (Monochromator B, TILL Photonics) with a $75 \mathrm{~W}$ xenon lamp to provide the two excitation wavelengths $(490 \mathrm{~nm}$ and $435 \mathrm{~nm})$. The inverted epifluorescence microscope (Zeiss Axiovert 135 TV) was equipped with a Zeiss Fluar $100 \times$ objective (numerical aperture 1.3), a dichroic mirror $(510 \mathrm{~nm})$ and an emission bandpass filter (515$565 \mathrm{~nm}$ ). Fluorescence emission was recorded on a cooled CCD camera (EEV $512 \times 1024,12$ bit frame transfer camera, Princeton Instruments).

Focusing was done with epifluorescent excitation $(450 \mathrm{~nm})$, in order to reduce photobleaching, as ordinary observation by transmitted light microscopy was not possible because of the experimental set-up.

Data analysis. Images were stored on a Pentium PC using Metafluor 3.0 (Universal Imaging). Data analysis was carried out on the saved experiment, and to analyse single cells, regions were drawn along the perimeter of the cell. The region data were directly logged into a spreadsheet. Cells were randomly selected on the $435 \mathrm{~nm}$ image (in order to avoid selection biased by a high intensity on the $490 \mathrm{~nm}$ image, which is $\mathrm{pH}$ dependent). Twenty cells were analysed in each experiment, unless stated otherwise. The $\mathbf{R}_{490 / 435}$ calculation was performed by dividing the intensity of individual pixels on the $490 \mathrm{~nm}$ image by the intensity of the corresponding pixels on the $435 \mathrm{~nm}$ image.

A calibration curve was constructed by plotting $\mathrm{R}_{490 / 435}$ versus $\mathrm{pH}$ of equilibrated cells in the range $\mathrm{pH} 5 \cdot 0-8 \cdot 5$, using linear interpolation between points. In order to convert the standard deviations from $\mathrm{R}_{490 / 435}$ to $\mathrm{pH}_{1}$, the minimal and maximal $\mathrm{R}_{490 / 435}$ were calculated (mean \pm standard deviation) and converted to minimal and maximal $\mathrm{pH}_{\mathrm{i}}$. Due to linear interpolation between the calibration points, the minimal or maximal $\mathrm{pH}_{1}$ values were, in a few cases, calculated from a slightly different equation (max. error $\leqslant 0.05 \mathrm{pH}$ units). In all cases, the largest value was chosen to represent a given $\mathrm{pH}$.

The ratio images were generated using the Intensity Modulated Display (IMD) mode of Metafluor. The settings for IMD were 16 ratios with 16 intensities. The range of colours in the image spans the $R_{490 / 435}$ values of the apparent minimum and maximum $\mathrm{pH}_{\mathrm{i}}$ in the respective image. The $\mathrm{pH}$ scale bar was generated in Metafluor and representative $\mathrm{pH}$ values were 
added next to the colour of the corresponding $R_{490 / 435}$. A thorough description of the IMD mode used to generate these images is given by Tsien \& Harootunian (1990). In short, this display mode takes the intensity of individual pixels into account when creating the ratio image, thereby creating a uniform black background.

\section{RESULTS}

\section{Definition of experimental parameters for fluorescence ratio imaging}

A solution of $5 \mu \mathrm{M}$ carboxyfluorescein in phosphate buffer $\mathrm{pH} 8.0$ was used to examine the response of the system. Fig. 1 shows the fluorescence intensities at $490 \mathrm{~nm}$ ( $\mathrm{pH}$-dependent) and $435 \mathrm{~nm}$ ( $\mathrm{pH}$-independent) and the corresponding ratio $\left(\mathrm{R}_{\mathbf{4 9 0 / 4 3 5}}\right)$, at various intensities of excitation light controlled by a range of neutral-density filters. The $\mathrm{pH}$ and concentration of carboxyfluorescein were selected to obtain a strong signal and to avoid quenching (Guldfeldt $\&$ Arneborg, 1998). It can be seen that the emission intensities at both wavelengths as well as $R_{490 / 435}$ change proportionally to the altered light intensity. As the emission returns to the original level when the light intensity is increased again, photobleaching is negligible in this experiment.

The observation that $\mathrm{R}_{\mathbf{4 9 0 / 4 3 5}}$ changes with excitation light intensity was also made with immobilized cells of Lb. delbrueckii subsp. bulgaricus, stained with carboxyfluorescein succinimidyl ester. However, subtraction of the background intensity (representative region with no cells) from both images, i.e. at $490 \mathrm{~nm}$ and $435 \mathrm{~nm}$, prior to the calculation rendered $R_{490 / 435}$ practically independent of the intensity of excitation light (Fig. 2).

To minimize photobleaching of the stained cells, a neutral-density filter with $2.5 \%$ throughput was chosen to reduce the excitation light intensity. This also reduced

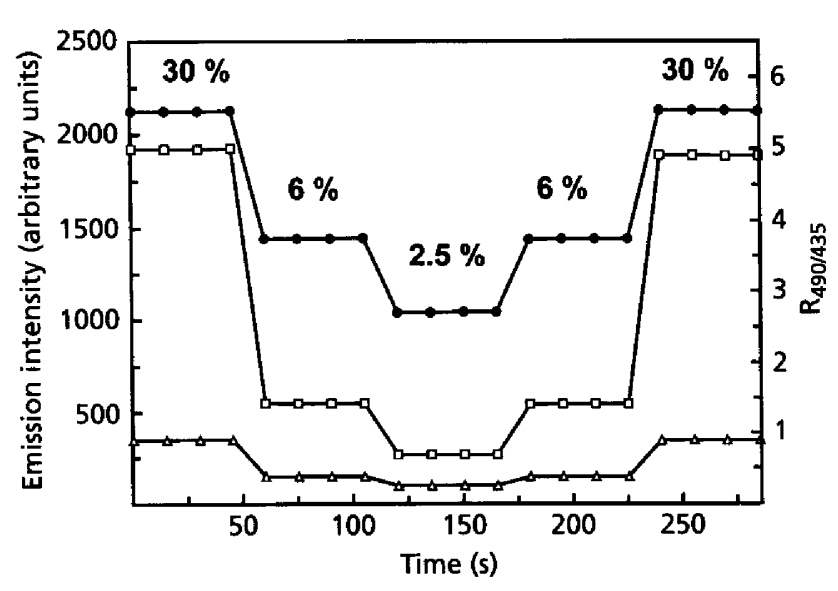

Fig. 1. Influence of excitation light intensity on emission of a solution of carboxyfluorescein $(5 \mu \mathrm{M})$. Emission intensities at excitation wavelengths of $490 \mathrm{~nm}(\square)$ and $435 \mathrm{~nm}(\triangle)$, and $\mathrm{R}_{490 / 435}(\mathrm{O})$, were recorded at $15 \mathrm{~s}$ intervals, while different neutral-density filters $(2.5 \%, 6 \%$ or $30 \%$ throughput) were inserted into the excitation light path.



Fig. 2. Influence of background subtraction on $R_{490 / 435}$ of $L b$. delbrueckii subsp. bulgaricus stained with carboxyfluorescein succinimidyl ester, at different levels of excitation light intensity (100\% and $2.5 \%$ throughput), before $(0)$ and after $(O)$ background subtraction. Each point represents the mean of 20 individual cells, with error bars indicating the standard deviation.

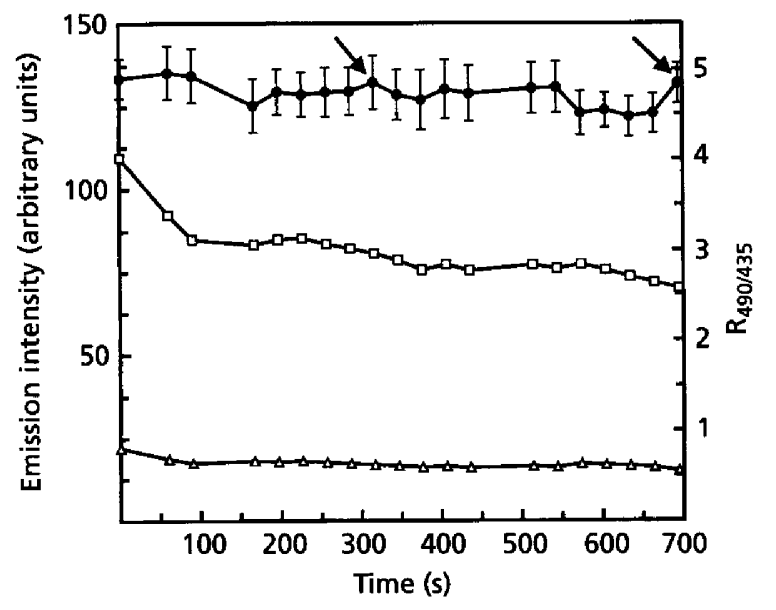

Fig. 3. Emission intensities at $490 \mathrm{~nm}(\square)$ and $435 \mathrm{~nm}(\triangle)$, and $\mathbf{R}_{490 / 435}(\mathbf{O})$, for 10 randomly selected cells of $L b$. delbrueckii subsp. bulgaricus, excited more than 20 times over a period of $12 \mathrm{~min}$. Even though the intensities decrease, $R_{490 / 435}$ is not significantly affected. The small variations in $R_{490 / 435}$ appear to be caused by focus drift, as refocusing (indicated by arrows) restores the ratio.

the emission and it was therefore necessary to increase the acquisition time to $3 \mathrm{~s}$ for both wavelengths to obtain a sufficient signal.

After determination of the optimal experimental parameters, it was possible to perform long-term experiments with multiple exposures and a constant $R_{490 / 435}$. Fig. 3 shows the result from following 10 randomly selected cells of $L b$. delbrueckii subsp. bulgaricus over a period of $12 \mathrm{~min}$ with more than 20 subsequent exposures. It can be seen that emission intensities 


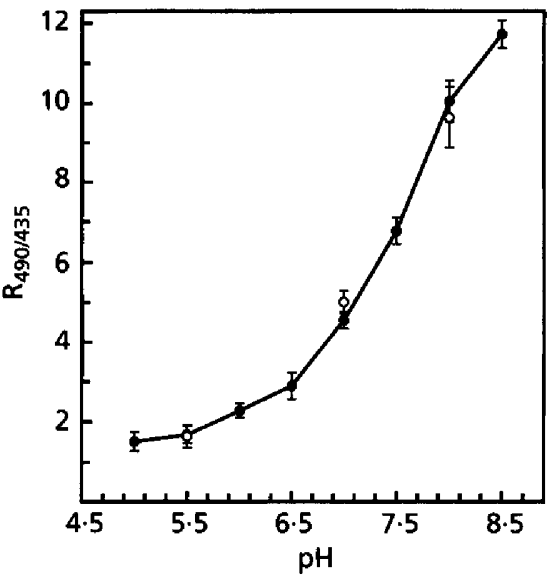

Fig. 4. Calibration curve of $L b$. delbrueckii subsp. bulgaricus (O) and $L$. innocua $(O)$ : $R_{490 / 435}$ versus $\mathrm{pH}_{\mathrm{i}}$. The $\mathrm{pH}_{\mathrm{i}}$ was equilibrated to $\mathrm{pH}_{\mathrm{ex}}$ by incubation with $1 \mu \mathrm{M}$ valinomycin and $1 \mu \mathrm{M}$ nigericin. Each point represents the mean of 20 individual cells, with error bars indicating the standard deviation.

decreased slowly but steadily throughout the experiment, whereas $\mathrm{R}_{\mathbf{4 9 0 / 4 3 5}}$ remained almost constant. The slight variations in $R_{490 / 435}$ are primarily due to focus drift, as refocusing restored $R_{490 / 435}$ to its original value, indicated by the arrows in Fig. 3. The emission intensities did not increase when the sample was refocused, which might be due to a slight bleaching during focusing.

\section{Calibration curve for measuring $\mathrm{pH}_{\mathrm{i}}$ in single cells}

The calibration curve of valinomycin- and nigericintreated cells of $L b$. delbrueckii subsp. bulgaricus suspended in buffers of different $\mathrm{pH}$ is shown in Fig. 4. The relationship between $\mathrm{R}_{490 / 435}$ and $\mathrm{pH}_{i}$ is non-linear and calculation of $\mathrm{pH}_{\mathrm{i}}$ values from the calibration curve was performed by linear interpolation. The sensitivity of the probe is greatest at $\mathrm{pH} 5 \cdot 5-8 \cdot 0$. The slope levels off in the low-pH range, and no determinations below 5.0 were attempted. The calibration points of $L$. innocua are almost superimposed on the calibration curve of $L b$. delbrueckii subsp. bulgaricus (Fig. 4), which was used for both species.

The accuracy of this method is described by the observed standard deviations, corresponding to errors smaller than $0.2 \mathrm{pH}$ unit in the $\mathrm{pH}_{\mathrm{i}}$ range from 5.5 to 8.5 . This also includes the relatively large standard deviation of $L$. innocua at $\mathrm{pH} 8$, which results in an error of $0.15 \mathrm{pH}$ units. The calibration points were reproducible in repeated determinations (results not shown).

\section{Effect of $\mathrm{pH}_{\mathrm{ex}}$ on $\mathrm{pH}_{\mathrm{i}}$ of $L b$. delbrueckii subsp. bulgaricus and $L$. innocua}

The difference in $\mathrm{pH}$ regulation between $L b$. delbrueckii subsp. bulgaricus and L. innocua in the $\mathrm{pH}_{\mathrm{ex}}$ range 5-8

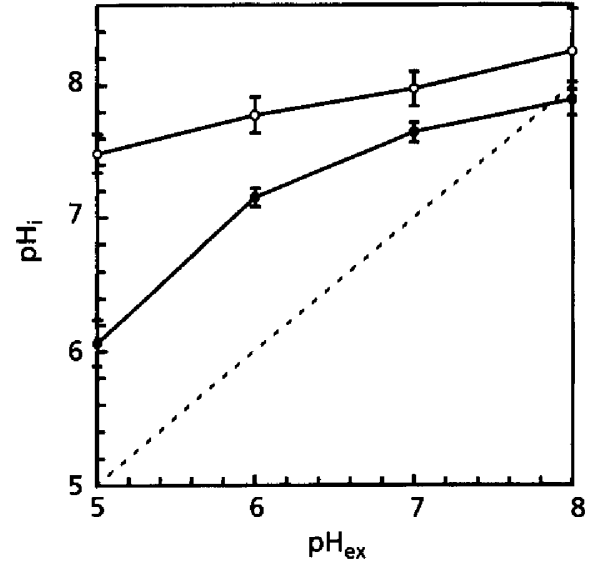

Fig. 5. $\mathrm{pH}_{\mathrm{i}}$ of pure cultures of $L b$. delbrueckii subsp. bulgaricus (O) and $L$. innocua $(O)$ in the presence of $10 \mathrm{mM}$ glucose at different $\mathrm{pH}_{\mathrm{ex}}$. Each point represents the mean of 20 individual cells, with error bars indicating the standard deviation. The dashed line represents $\mathrm{pH}_{\mathrm{i}}=\mathrm{pH}_{\mathrm{ex}}$.

is illustrated in Fig. 5. The cultures were examined in the presence of glucose $(10 \mathrm{mM})$, and the values therefore represent the $\mathrm{pH}_{\mathrm{i}}$ regulation of metabolically active cells. Each point indicates the mean and standard deviation of $\mathrm{pH}_{\mathrm{i}}$ of 20 individual cells calculated from the respective $\mathrm{R}_{490 / 435}$ values. The $\Delta \mathrm{pH}$ in Lb. delbrueckii subsp. bulgaricus is suspended at $\mathrm{pH} 8$, where the $\mathrm{pH}_{\mathrm{i}}$ is actually lower than the $\mathrm{pH}_{\mathrm{ex}}$, and $\Delta \mathrm{pH}$ increases steadily with decreasing $\mathrm{pH}_{\mathrm{ex}}$ until a $\mathrm{pH}_{\mathrm{ex}}$ of 6 . The decrease in $\mathrm{pH}_{\mathrm{i}}$ from $\mathrm{pH}_{\mathrm{ex}} 6$ to $\mathrm{pH}_{\mathrm{ex}} 5$ is more pronounced, and the $\Delta \mathrm{pH}$ is approximately $1 \mathrm{pH}$ unit. In $L$. innocua, the decrease in $\mathrm{pH}_{\mathrm{i}}$ is linear but minor, and the $\Delta \mathrm{pH}$ increases at low $\mathrm{pH}_{\mathrm{ex}}$. The $\mathrm{pH}_{\mathrm{i}}$ in single cells can also be presented by ratio images with a colour-coded $\mathrm{pH}$ scale, as can be seen in Fig. 6(a,b). The non-linear $\mathrm{pH}$ scale is numerically equivalent to Fig. 4 , and the $\mathrm{pH}_{\mathrm{i}}$ is described by the colour hues.

The mean $\mathrm{pH}_{\mathrm{i}}$ values of a population of $L b$. delbrueckii subsp. bulgaricus and $L$. innocua, at a $\mathrm{pH}_{\mathrm{ex}}$ of $7 \cdot 0$, are 7.7 and 8.0 , respectively. The images in Fig. $6(\mathrm{a}, \mathrm{b})$ are from a different experiment than the results presented in Fig. 5, but the results are identical, confirming the reproducibility of the method applied.

\section{Determining $\mathrm{pH}_{\mathrm{i}}$ in a mixed culture}

Mixing $L b$. delbrueckii subsp. bulgaricus and L. innocua prior to staining allowed us to determine $\mathrm{pH}_{\mathrm{i}}$ in single cells within a mixed culture. The two species still regulated $\mathrm{pH}_{\mathrm{i}}$ differently at both high and low $\mathrm{pH}_{\mathrm{ex}}$ (Fig. 6c and d, respectively). L. innocua maintains a considerably higher $\mathrm{pH}_{\mathrm{i}}$ than $L b$. delbrueckii subsp. bulgaricus regardless of $\mathrm{pH}_{\mathrm{ex}}$. Furthermore, the $\mathrm{pH}_{\mathrm{i}}$ of the species in a mixture at $\mathrm{pH}_{\mathrm{ex}} 7$ (Fig. 6c) corresponds well to the experiments performed on the pure cultures at the same $\mathrm{pH}_{\mathrm{ex}}$ (Fig. 6a, b). 

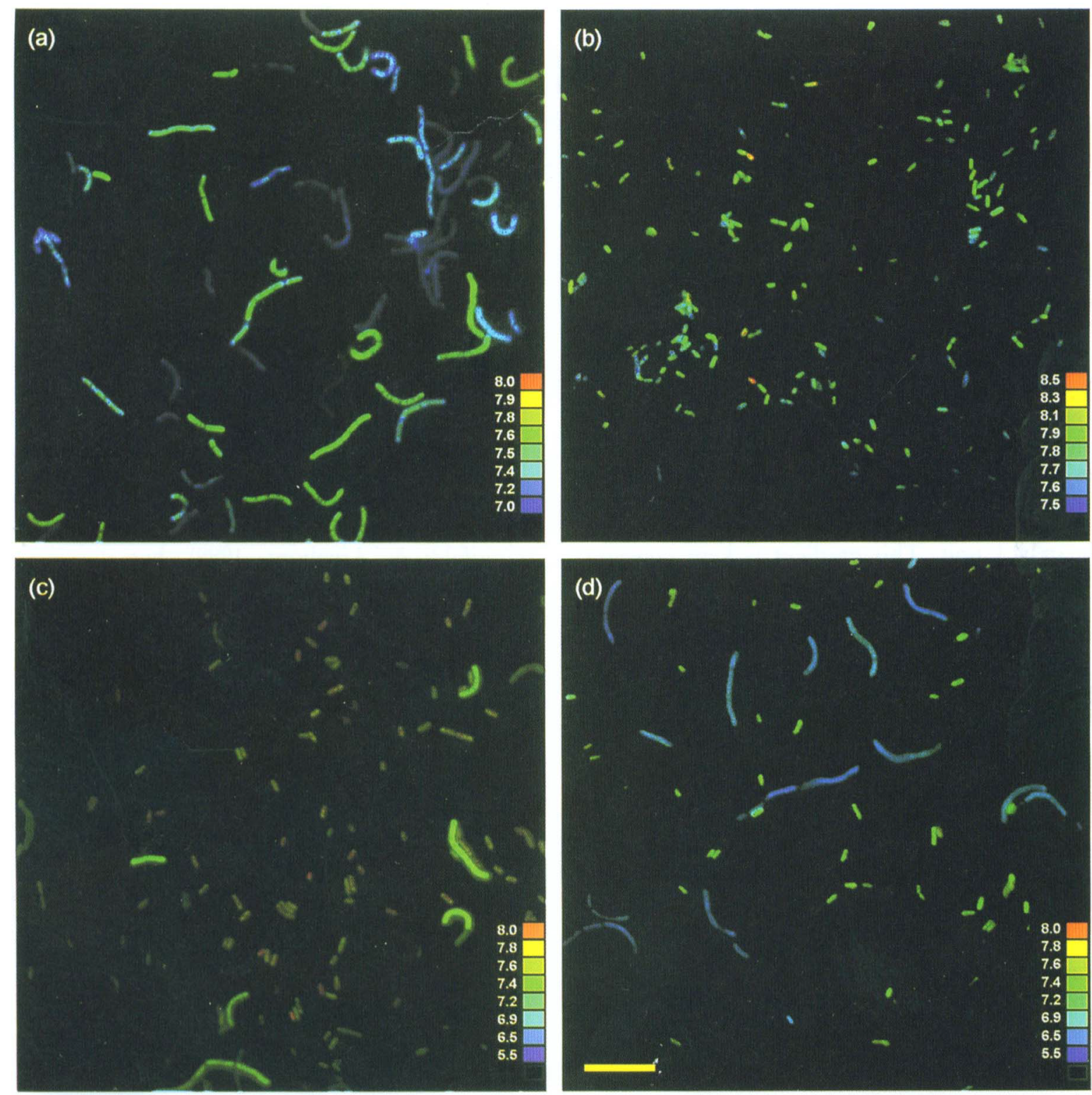

Fig. 6. Ratio images of $L b$. delbrueckii subsp. bulgaricus and $L$. innocua in the presence of $10 \mathrm{mM}$ glucose. (a, b) Pure cultures of $L b$. delbrueckii subsp. bulgaricus (a) and $L$. innocua (b) at $\mathrm{pH}_{\mathrm{ex}} 7$. (c, d) A mixed culture of $L b$. delbrueckii subsp. bulgaricus (large rods in pairs and chains) and $L$. innocua (small rods) at $\mathrm{pH}_{\mathrm{ex}} 7$ (c), and after further incubation with $10 \mathrm{mM}$ glucose for $15 \mathrm{~min}$ at $\mathrm{pH}_{\mathrm{ex}} 5$ (d). Bar, $10 \mu \mathrm{m}$. A colour-coded $\mathrm{pH}$ scale is shown in each panel.

\section{DISCUSSION}

In contrast to previous methods based upon ion distribution of radiolabelled cells (Rottenberg, 1979$),{ }^{31} \mathrm{P}$ NMR ;Foucaud et al., 1995; or spectrofluorometry (Molenaar et al., 1991; Breeuwer et al., 1996; Aono et al., 1997), our experimental approach allows a rapid $\mathrm{pH}_{\mathrm{i}}$ measurement of single bacterial cells in time-lapsc studies.

Problems inherent to fluorescence microscopy of lowlight-level objects have been overcome, and the fluorescent probe gives a good cstimation of $\mathrm{pH}_{\mathrm{i}}$ between 5.5 and 8.5 . The useful range of fluorescent $\mathrm{pH}$ indicators is mostly determined by their $\mathrm{p} K_{a}$, and probes with lower $\mathrm{pk}_{\mathrm{a}}$ are commercially available (see Molecular Prohes at http://www.probes.com). I Iowever, these probes generally suffer from lack of sensitivity in the near-ncutral pI I range, and therefore it is important to establish the $\mathrm{pH}$ range of a study prior to selection of probes. The presence of a succinimidyl ester group reduces the cfflux significantly (Breeuwer et al., 1996), and continuous background subtraction eliminates errors from potential extracellular carboxyfluorescin.

In a study by Cimprich et al. (1995) on ycast cells, it was stated that the emission from stained cells was sufficiont to neglect background subtraction. The smaller size of the bacteria in our study, and the necessity of reducing 
the excitation intensity in order to minimize photobleaching, reduces the overall fluorescence intensity of the cell. In addition, the CCD camera produces a small overall background that is not linked to the fluorescent probe. As the fluorescence intensity of cells decreases, the relative contribution from this overall background increases, rendering background subtraction necessary, as performed in the present work.

The design of the closed perfusion chamber has the potential for dynamic measurements of $\mathrm{pH}_{i}$ in a changing environment. Due to the presence of liquid in the chamber, the micro-organisms are not likely to suffer from nutrient exhaustion as in experiments with cells localized between slide and coverslip.

It is accepted that $L b$. delbrueckii subsp. bulgaricus does not maintain a $\mathrm{pH}_{\mathrm{i}}$ close to neutrality when $\mathrm{pH}_{\mathrm{ex}}$ decreases (Kashket, 1987), but the $\mathrm{pH}_{\mathrm{i}}$ is clearly regulated as a function of $\mathrm{pH}_{\mathrm{ex}}$. From $\mathrm{pH}_{\mathrm{ex}} 8$ to 6 , there is an increase in $\Delta \mathrm{pH}$ in $L b$. delbrueckii subsp. bulgaricus to approximately 1 unit. This gradient is kept constant when $\mathrm{pH}_{\mathrm{ex}}$ is reduced to 5 , which is in agreement with earlier reports stating that acid-tolerant bacteria, such as lactobacilli, maintain a constant $\Delta \mathrm{pH}$ of approximately 1 at low $\mathrm{pH}_{\text {ex }}$ (Kashket, 1987; Russell, 1992; Hutkins \& Nannen, 1993). It has been suggested that $\mathrm{pH}_{i}$ decreases only upon energy limitation (Poolman et al., 1987), but our results on Lb. delbrueckii subsp. bulgaricus as well as earlier reports on Streptococcus bovis and Lactococcus lactis (Cook \& Russell, 1994) demonstrate that $\mathrm{pH}_{\mathrm{i}}$ decreases as a function of $\mathrm{pH}_{\mathrm{ex}}$ in the presence of glucose. As bacteria maintaining a constant $\Delta \mathrm{pH}$ rather than a constant $\mathrm{pH}_{\mathrm{i}}$ are not $\mathrm{pH}$-homeostatic in the classical sense (Padan et al., 1981), these bacteria might be recognized as a distinct class.

$\mathrm{H}^{+}$-ATPase has been shown to be the key enzyme in regulating $\mathrm{pH}_{\mathrm{i}}$ in Enterococcus faecalis (Kobayashi et al., 1986), and it is also assumed to regulate $\mathrm{pH}_{\mathrm{i}}$ in lactic acid bacteria (Nannen \& Hutkins, 1991b). In $L b$. delbrueckii subsp. bulgaricus, the onset of the constant $\Delta \mathrm{pH}$ at $\mathrm{pH}_{\mathrm{ex}} 6$ coincides with the optimal $\mathrm{pH}_{\mathrm{ex}}$ for growth of 5.8 (Beal et al., 1989), indicating a tighter control of $\mathrm{pH}_{\mathrm{i}}$ at acidic $\mathrm{pH}_{\mathrm{ex}}$. This is further supported by the significantly lower $\mathrm{pH}$ optimum for $\mathrm{H}^{+}$-ATPase (5.0) of an acid-tolerant bacterium, Lactobacillus case $i$ (Bender \& Marquis, 1987), compared to the less acidtolerant Streptococcus thermophilus and Lactococcus lactis with a $\mathrm{pH}$ optimum of 7.5 (Nannen \& Hutkins, 1991b). The presence of short fatty acid anions such as lactate and acetate is also involved in the regulation of $\mathrm{pH}_{\mathrm{i}}$ in acid-tolerant bacteria (Russell, 1991a; Cook \& Russell, 1994); however, this factor has not been investigated in the present work.

The much smaller size of L. innocua is a challenge when measuring $\mathrm{pH}_{\mathrm{i}}$ in single cells, and the lower fluorescence intensity is probably the reason for the somewhat larger standard deviations observed for this bacterium, even when $\mathrm{pH}_{\mathrm{i}}$ and $\mathrm{pH}_{\mathrm{ex}}$ are equilibrated (Fig. 4). L. innocua has previously been investigated with regard to $\mathrm{pH}_{\mathrm{i}}$ by spectrofluorometry (Breeuwer et al., 1996), and the $\mathrm{pH}_{\mathrm{i}}$ results on single cells of L. innocua obtained in this study are in agreement with the results obtained on a population of the same bacteria.

The accuracy of the method (to within $0.2 \mathrm{pH}$ units) is determined by the standard deviations in the calibration curve (Fig. 4). A change in focus alters $\mathrm{R}_{490 / 435}$ slightly (Fig. 3), and some of the equilibrated cells used for calibration may have been slightly out of focus, thus causing the deviations in $\mathrm{R}_{\mathbf{4 9 0 / 4 3 5}}$. However, visual examination of the images does not reveal the examined cells to be obviously out of focus (results not shown).

To our knowledge, there are no other published reports describing the $\mathrm{pH}_{\mathrm{i}}$ variation within a bacterial population. The populations investigated in the present study revealed $\mathrm{pH}_{\mathrm{i}}$ standard deviations of $0 \cdot 1-0 \cdot 3$ units (Fig. $5)$; this is only slightly higher than accounted for by the calibration accuracy (Fig. 4). Results published on the yeast Saccharomyces cerevisiae have reported standard deviations in $\mathrm{pH}_{\mathrm{i}}$ of $0 \cdot 15-0 \cdot 25$ (Cimprich et al., 1995; Guldfeldt \& Arneborg, 1998), but the influence of method artefacts (e.g. focus drift) on deviations in $\mathrm{pH}_{\mathrm{i}}$ was not assessed.

As shown in the present study, we are now able to measure $\mathrm{pH}_{\mathrm{i}}$ in individual bacterial cells in mixed cultures. In most natural habitats, bacteria are exposed to more stressful conditions than investigated here. For example, bacterial populations present in food (desired micro-organisms as well as natural contaminants) are generally heterogeneous, and differences in physiological state will probably be reflected in variations of $\mathrm{pH}_{\mathrm{i}}$ and $\Delta \mathrm{pH}$. Work is in progress on studying $\mathrm{pH}_{\mathrm{i}}$ of individual cells in natural environments. Additionally, we expect to be able to monitor $\mathrm{pH}_{\mathrm{i}}$ in micro-organisms on solid substrates such as cheese or meat surfaces.

\section{ACKNOWLEDGEMENTS}

The skilful technical assistance of S. Houran is gratefully acknowledged. We would like to thank Dr P. G. Meaden and Dr N. Arneborg for critical reading of the manuscript. This work is part of the FØTEK2 programme supported by the Danish Dairy Research Foundation (Danish Dairy Board) and the Danish Government.

\section{REFERENCES}

Aono, R., Ito, M. \& Horikoshi, K. (1997). Measurement of cytoplasmic $\mathrm{pH}$ of the alkaliphile Bacillus lentus C-125 with a fluorescent $\mathrm{pH}$ probe. Microbiology 143, 2531-2536.

Auclair, J. \& Accolas, J. P. (1983). Use of thermophilic lactic starters in the dairy industry. Antonie Leeuwenboek 49, 313-326.

Beal, C., Louvet, P. \& Corrieu, G. (1989). Influence of controlled $\mathrm{pH}$ and temperature on the growth and acidification of pure cultures of Streptococcus thermophilus 404 and Lactobacillus bulgaricus 398. Appl Microbiol Biotechnol 32, 148-154.

Bender, G. R. \& Marquis, R. E. (1987). Membrane ATPases and acid tolerance of Actinomyces viscosus and Lactobacillus casei. Appl Environ Microbiol 53, 2124-2128.

Breeuwer, P., Drocourt, J. L., Rombouts, F. M. \& Abee, T. (1996). A novel method for continuous determination of the intracellular 
$\mathrm{pH}$ in bacteria with the internally conjugated fluorescent probe 5 (and 6-)-carboxyfluorescein succinimidyl ester. Appl Environ Microbiol 62, 178-183.

Cimprich, P., Slavik, J. \& Kotyk, A. (1995). Distribution of individual cytoplasmic $\mathrm{pH}$ values in a population of the yeast Saccharomyces cerevisiae. FEMS Microbiol Lett 130, 245-252.

Cook, G. M. \& Russell, J. B. (1994). The effect of extracellular $\mathrm{pH}$ and lactic acid on $\mathrm{pH}$ homeostasis in Lactococcus lactis and Streptococcus bovis, Curr Microbiol 28, 165-168.

Diez-Gonzales, F. \& Russell, J. B. (1997). The ability of Escherichia coli $\mathrm{O} 157: \mathrm{H} 7$ to decrease its intracellular $\mathrm{pH}$ and resist the toxicity of acetic acid. Microbiology 143, 1175-1180.

Foucaud, C., Herve, M., Neumann, J. M. \& Hemme, D. (1995). Glucose metabolism and internal $\mathrm{pH}$ of Lactococcus lactis subsp. lactis cells utilizing NMR spectroscopy. Lett Appl Microbiol 21, 10-13.

Guldfeldt, L. U. \& Arneborg, N. (1998). Measurements of the effects of acetic acid and extracellular $\mathrm{pH}$ on intracellular $\mathrm{pH}$ of nonfermenting, individual Saccharomyces cerevisiae cells by fluorescence microscopy. Appl Environ Microbiol 64, 530-534.

Hansen, T. K. \& Jakobsen, M. (1997). Possible role of microbial interactions for growth and sporulation of Penicillium roqueforti in Danablu. Lait 77, 479-488.

Holzapfel, W. H. \& Wood, J. B. (1995). Lactic acid bacteria in contemporary perspective. In The Genera of Lactic Acid Bacteria, pp. 1-6. Edited by B. J. B. Wood \& W. H. Holzapfel. London: Blackie Academic \& Professional.

Hutkins, R. W. \& Nannen, N. L. (1993). pH homeostasis in lactic acid bacteria. J Dairy Sci 76, 2354-2365.

Kashket, E. R. (1987). Bioenergetics of lactic acid bacteria: cytoplasmic $\mathrm{pH}$ and osmotolerance. FEMS Microbiol Rev 46, 233-244.

Kobayashi, H., Suzuki, T. \& Unemoto, T. (1986). Streptococcal cytoplasmic $\mathrm{pH}$ is regulated by changes in amount and activity of a proton-translocating ATPase. J Biol Chem 261, 627-630.

McDonald, L. C., Fleming, H. P. \& Hassan, H. M. (1990). Acid tolerance of Leuconostoc mesenteroides and Lactobacillus plantarum. Appl Environ Microbiol 56, 2120-2124.
Molenaar, D., Abee, T. \& Konings, W. N. (1991). Continuous measurement of the cytoplasmic $\mathrm{pH}$ in Lactococcus lactis with a fluorescent $\mathrm{pH}$ indicator. Biochim Biophys Acta 1115, 75-83.

Nannen, N. L. \& Hutkins, R. W. (1991a). Intracellular pH effects in lactic acid bacteria. J Dairy Sci 74, 741-746.

Nannen, N. L. \& Hutkins, R. W. (1991b). Proton-translocating adenosine triphosphatase activity in lactic acid bacteria. $J$ Dairy Sci 74, 747-751.

Padan, E., Zilberstein, D. \& Schuldiner, S. (1981). pH homeostasis in bacteria. Biochim Biophys Acta 650, 151-166.

Poolman, B., Driessen, A. J. \& Konings, W. N. (1987). Regulation of solute transport in streptococci by external and internal $\mathrm{pH}$ values. Microbiol Rev 51, 498-508.

Rottenberg, H. (1979). The measurement of membrane potential and $\Delta \mathrm{pH}$ in cells, organelles, and vesicles. Methods Enzymol 55, 547-587.

Russell, J. B. (1991a). Resistance of Streptococcus bovis to acetic acid at low $\mathrm{pH}$ : relationship between intracellular $\mathrm{pH}$ and anion accumulation. Appl Environ Microbiol 57, 255-259.

Russell, J. B. (1991b). Intracellular $\mathrm{pH}$ of acid-tolerant ruminal bacteria. Appl Environ Microbiol 57, 3383-3384.

Russell, J. B. (1992). Another explanation for the toxicity of fermentation acids at low $\mathrm{pH}$ : anion accumulation versus uncoupling. J Appl Bacteriol 73, 363-370.

Russell, J. B. \& Hino, T. (1985). Regulation of lactate production in Streptococcus bovis: a spiraling effect that contributes to rumen acidosis. J Dairy Sci 68, 1712-1721.

Tsien, R. Y. \& Harootunian, A. T. (1990). Practical design criteria for a dynamic ratio imaging system. Cell Calcium 11, 93-109.

White, D. (1995). Homeostasis. In The Physiology and Biochemistry of Prokaryotes, pp. 294-305. New York: Oxford University Press.

Received 18 December 1998; revised 9 March 1999; accepted 30 March 1999. 